\title{
CO2 Emission - The Leading Environmental Threat To India
}

\author{
Kadalarasane. T., Tripura Sundari.C.U.
}

\begin{abstract}
The 2030 Agenda of 17 Sustainable Development Goals is to promote well being, peace and prosperity among people at presents and future. Goal 9 focuses on "Build resilient infrastructure, promote inclusive and sustainable industrialization and foster innovation". The score of this goal according to Sustainable Development report is 33.1. Air pollution is the top killer in the world (Thomson Reuters 2018), every year all countries face heavy natural calamities disaster which results in huge human loss and financial losses thereby leading to global inequality and environmental injustice. The most important source of global warming is Tropical deforestation, rising the release of different gases into the atmosphere, burning of fossil fuels etc. Increase in $\mathrm{CO} 2$ emissions will produce more heat, thereby directly affecting our natural resources which results in more disease and increase in water level. Almost all countries contribute to the rise of carbon emission, the Paris agreement pledges that nearly 200 nations will limit global warming to $3 C$. India is the second largest populated country, it has launched the smart city project, Government wants to implement 100 smart cities, and it is worth to develop 100 smart villages. Smart class rooms, good and healthy environment and hospitals must be focused and developed in villages, which will act as a tool to achieve 2030 Goal. Based on the above theory the current paper attempts to study the world and region wise data regarding the human impacts of fossil-fuel pollution, Worlds' Ranking on fossil fuel CO2 emissions rates, waterless economies, Investment potential and opportunities in cities by region and sector to 2030 etc. Secondary data of various sources from Sustainable Development report, water polluted report, Carbon dioxide Information Analysis, world bank, etc., is collected. Simple graphs, growth rate, percentage analysis, data visualization techniques are used to verify the above objective, based on the detail discussions, policy suggestions are provided.

Keywords : climate change, $\mathrm{CO} 2$ emission, Fossil fuel, Paris agreement, smart village, sustainable development Goal, urbanization.
\end{abstract}

\section{INTRODUCTION}

This "Sustainability focuses on meeting the needs of the present without compromising the ability of future generation's needs" UNCED (1992). The 2030 Agenda of 17 Sustainable Development Goals is to promote wellbeing, peace and prosperity among people at presents and future. Goal 9 focuses on " Build resilient infrastructure, promote inclusive and sustainable industrialization and foster innovation". The score of this goal according to Sustainable Development report is 33.1. As per World Resources Institute (1996), "World's population is around 7.04 billion and is expected to grow between 17.9 billion to 21.9 billion

Revised Manuscript Received on September 10, 2019.

Kadalarasane T, Quantitative Finance program, Department of Statistics, Pondicherry University, Pondicherry, India.

(Email:kada1009@gmail.com)

Tripura Sundari.C.U., Quantitative Finance program, Department of

(Email:tsundari30@gmail.com) Statistics, Pondicherry University, Pondicherry, India.

by $2050 "$. "In the same period, the global economy will grow four to five times its present size, as a result, industrialized nations will need to reduce material through energy use and environmental degradation by more than 90 percent by 2040" World Resources Institute (1997). Due to the advancement of industrial revolution the polluted gas is pumped into the atmosphere which leads to warming the planet and rise in sea level which may result in serious food shortage.

Almost all countries contribute to the rise of carbon emission, the Paris agreement pledges that nearly 200 nations will limit global warming to $3 \mathrm{C}$. Increase in $\mathrm{CO} 2$ emissions will produce more heat, increased toxic pollutants in atmosphere, thereby directly affecting the natural resources which results in more disease and increase in water level. Survival is becoming very difficult because Fossil-fuel combustion, which is the world's most significant threat to the universe. According to United Nations climate change panel, just 100 companies have been the source of more than $70 \%$ of the world's greenhouse gas emissions since 1988. (IPCC,2017).

Table 1: Top 100 producers and their cumulative greenhouse gas emissions from 1988-2015

\begin{tabular}{|c|c|c|}
\hline Count & Company & $\begin{array}{c}\text { Percentage of global } \\
\text { industrial } \\
\text { greenhouse gas } \\
\text { emissions }\end{array}$ \\
\hline 1 & China (Coal) & $14.32 \%$ \\
\hline 2 & $\begin{array}{l}\text { Saudi Arabian Oil } \\
\text { Company (Aramco) }\end{array}$ & $4.50 \%$ \\
\hline 3 & Gazprom OAO & $3.91 \%$ \\
\hline 4 & National Iranian Oil Co & $2.28 \%$ \\
\hline 5 & ExxonMobil Corp & $1.98 \%$ \\
\hline 6 & Coal India & $1.87 \%$ \\
\hline . & . & . \\
\hline . & . & . \\
\hline - & - & - \\
\hline . & . & . \\
\hline 96 & Murphy Oil Corp & $0.06 \%$ \\
\hline 97 & $\begin{array}{c}\text { Berau Coal Energy Tbk } \\
\text { PT }\end{array}$ & $0.06 \%$ \\
\hline 98 & $\begin{array}{c}\text { Bukit Asam (Persero) } \\
\text { Tbk PT }\end{array}$ & $0.05 \%$ \\
\hline 99 & Indika Energy Tbk PT & $0.04 \%$ \\
\hline 100 & Southwestern Energy Co & $0.04 \%$ \\
\hline
\end{tabular}

Source : CDP carbon majors report 2017 
Table 1 presents the top (few) 100 producers and their cumulative (1988-2015) greenhouse gas emissions from carbon majors report 2017. It is clear from the table that the major players contributing to climatic changes are coal, oil and gas companies.

The report by Inter governmental Panel on Climate Change (IPCC) warns that "even at $1.5^{\circ} \mathrm{C}$ warming, the planet will experience terrible climatic impact. Currently, more than half of the global population lives in urban areas, a figure expected to rise to $60 \%$ by 2030 . Cities consume over two-thirds of the world's energy and account for more than $70 \%$ of global carbon dioxide emissions, making them critical to efforts to limit global warming". Other than international organizations like WHO, WEF, IPCC etc Studies are conducted recently in this area of climatic change and carbon emission by Ramachandra et al., 2015, Rugayah Hashim et al., 2016,Amit Garg et al., 2017 and Katharine Ricke et al., 2018.

\section{A. Motivation of the study}

As per Thomson Reuters, "Air pollution is the top killer in the world", every year all countries face heavy natural calamities disaster which results in huge human loss and financial losses thereby leading to global disparity and ecological discrimination. Jakarta is a victim of climate change, about 10 million people are facing destruction by rising seas and sinking land. Experts predict that by 2050, 95 percent of North Jakarta could be underwater. (Jakarta Is Sinking. Now Indonesia Has to Find a New Capital | WIRED,2019). Coal contributes a larger share of fossil fuels. "If fossil fuels continue to be extracted at the same rate over the next 28 years as they were between 1988 and 2017 , says the report, global average temperatures would be on course to rise by $4 \mathrm{C}$ by the end of the century, which will be a real threat to the living organism".

\section{B. Objective and Methodology}

Based on the above theory the current paper attempts to study the world and region wise data regarding the human impacts of fossil-fuel pollution, highlighting the infrastructure developmental impacts, Worlds' Ranking on fossil fuel $\mathrm{CO} 2$ emissions rates, waterless economies, Investment potential and opportunities in cities by region and sector to 2030, based on urban population projections. Secondary data of various sources from Sustainable Development report, water polluted report, Carbon dioxide Information Analysis, world bank, etc., is collected. Time series data for world from 1863 to 2014, regarding World Total Fossil-Fuel Emissions and for Per capita emission the data collected is from 1950 to 2014. Simple graphs, growth rate, percentage analysis, data visualization technique are used to verify the above objective.

Introduction and motivation of the study is provided in section I , section II briefly explains the data analysis with the help of table and data visualization techniques and finally the conclusion and policy suggestions are provided in section III.

\section{DATA ANALYSIS, RESULT AND DISCUSSION}

Chart 1 provides the Worlds Total Fossil-Fuel emission from 1870 to 2014 , the chart clearly reveals the increase in the emission since 1950. A quadratic trend is found to fit the data set, and in this time series data and the growth rate of Fossil-Fuel emission for the period of 1870 to 2014 is calculated (using SPSS software, Appendix I)) to be 66.8 percent.

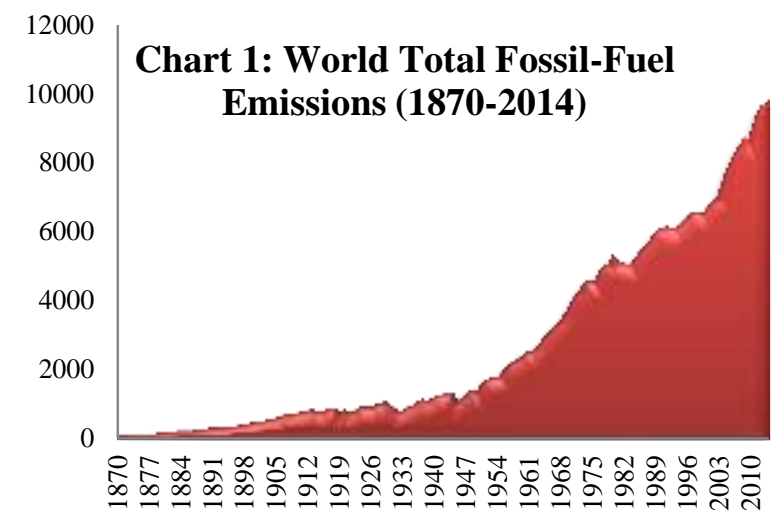

\section{Source: Computed from Carbon Dioxide Information Analysis center}

Table 2 provides the status of the worlds' countries from in 2014 per capita fossil fuel CO2 emissions rates. Qatar, ranks first with the total $\mathrm{CO} 2$ emission of 13.54 , it is the world's third largest natural gas reserve, the richest economies in the world based on per capita GDP and the second-largest exporter of natural gas. Curacao, has a per capita fossil fuel $\mathrm{CO} 2$ emissions rates of 10.3. Petroleum Refining and Petroleum Transshipment Facilities are the major industry located here. India's rank in the per capita fossil fuel $\mathrm{CO} 2$ emission is 140 , with an emission rate of 0.45 .

Table 2: Ranking of the worlds' countries by 2014 per capita fossil fuel $\mathrm{CO} 2$ emissions rates

\begin{tabular}{|c|c|c|}
\hline Rank & Nation & $\begin{array}{c}\mathrm{CO}_{2} \\
\text { Total }\end{array}$ \\
\hline 1 & Qatar & 13.54 \\
\hline 2 & Curacao & 10.3 \\
\hline 3 & $\begin{array}{c}\text { Trinidad and } \\
\text { Tobago }\end{array}$ & 9.32 \\
\hline 4 & Kuwait & 6.93 \\
\hline 5 & $\begin{array}{c}\text { United Arab } \\
\text { Emirates }\end{array}$ & 6.34 \\
\hline 6 & Bahrain & 6.28 \\
\hline 7 & Brunei (Darussalam) & 5.95 \\
\hline 8 & $\begin{array}{c}\text { Saint Martin (Dutch } \\
\text { Portion) }\end{array}$ & 5.31 \\
\hline 9 & Saudi Arabia & 5.31 \\
\hline 10 & $\begin{array}{c}\text { Falkland Islands } \\
\text { (Malvinas) }\end{array}$ & 5.16 \\
\hline 11 & Luxembourg & 4.73 \\
\hline 12 & New Caledonia & 4.5 \\
\hline 13 & 13 Gibraltar & 4.5 \\
\hline 14 & $\begin{array}{c}\text { United States of } \\
\text { America }\end{array}$ & 4.43 \\
\hline 140 & India & 0.45 \\
\hline
\end{tabular}

Source: Carbon Dioxide Information Analysis 
Chart 2, presents the world per capita (total emission divided by Population) emission from 1950-2014. It is very clear from the chart that in 1950 the per capita emission was 0.65 which increased over the years and in 2014 it reached 1.36 per head, which is a real threat to the economy, the reason can be industrialization, innovative technology, increase in population so the pollution through transport has increased over the years.

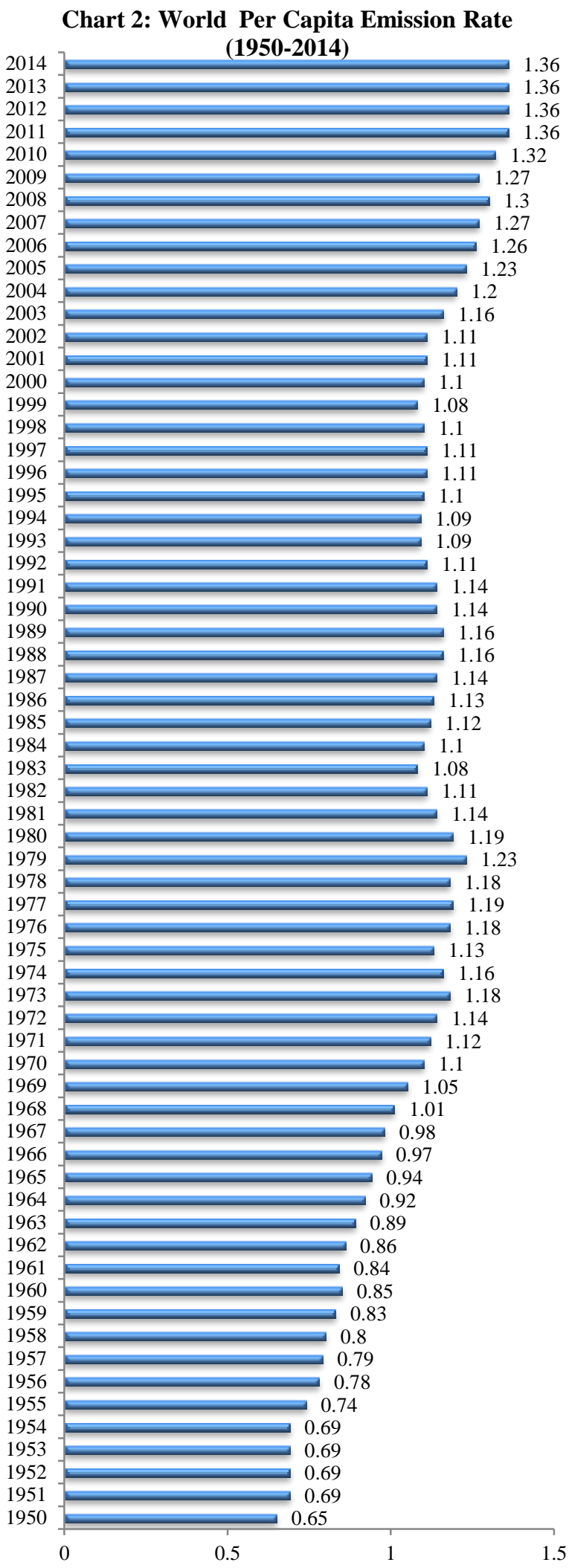

Source: computed from Carbon Dioxide Information

\section{Analysis center}

Chart 3: World region -wise Total Fossil-Fuel Emissions 1950-2014

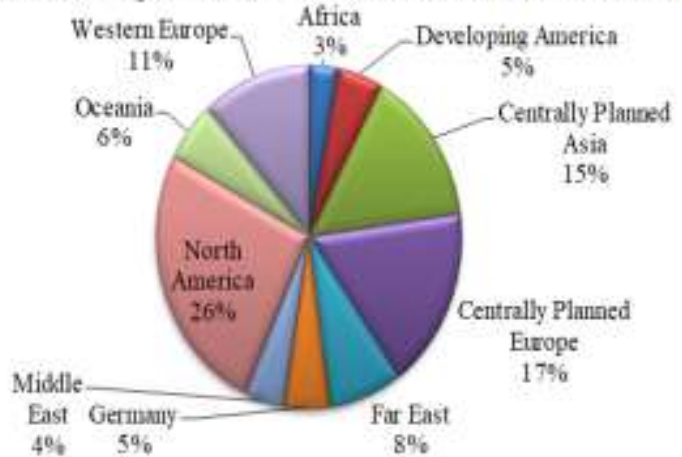

Source: computed from Carbon Dioxide Information Analysis

The Pie chart 3 provides the distribution of world regionwise total Fossil-Fuel Emissions 1950-2014. The chart clearly reveals that North America contributes 26 percent of total Fossil-Fuel Emissions, followed by centrally planned Europe and then by Asia which contributes 15 percent of the total Fossil- Fuel Emission.

Also, Chart 4 provides the world region wise per capita CO2 emission from 1950-2014. Per capita CO2 emission is found to be high in North America, followed by Germany and Europe.

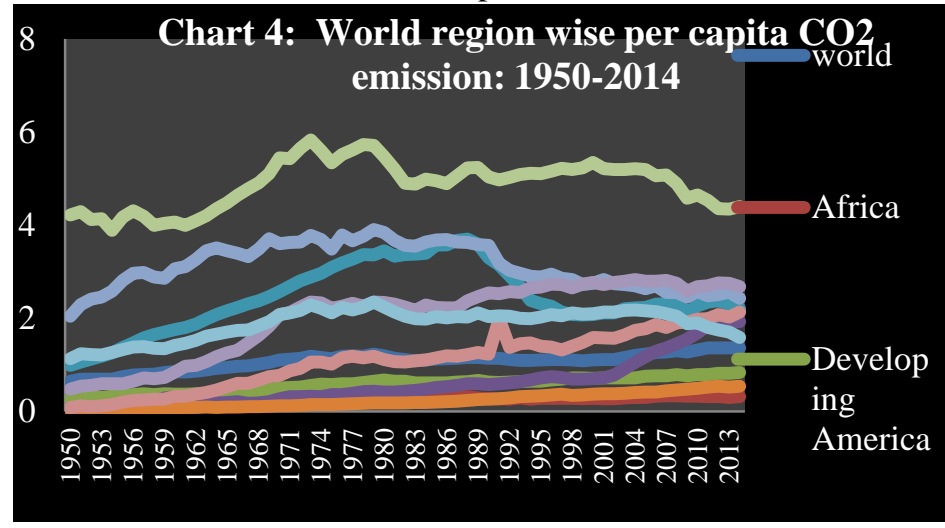

Source: computed from Carbon Dioxide Information Analysis center

The CO2 emission of world countries in 2014 is presented in chart 5. It is clear from the chart that the top 10 emitters were China, the US, the EU, India, Russia, Japan, Germany, Iran, Saudi Arabia and South Korea[1]. As per the first round of Paris Agreement in 2015, these economies are set to achieve more than what they agreed to review the commitments made during Paris Agreement. 
Chart 5: Ranking of the worlds' countries by 2014 total CO2 emissions

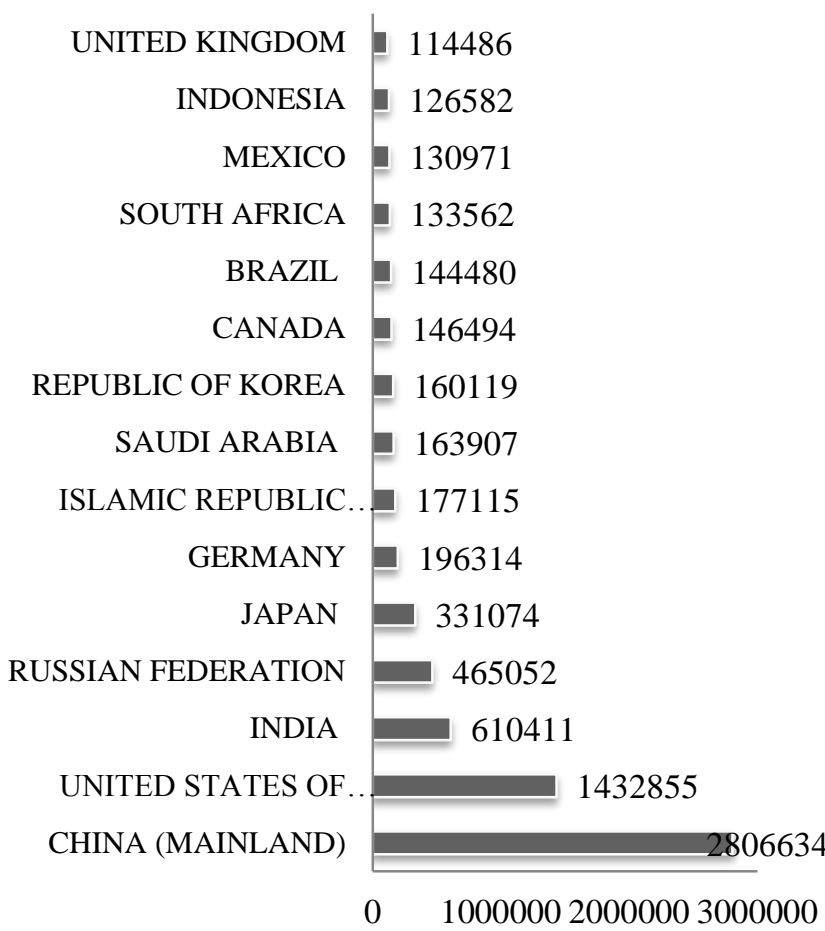

Source: Computed from Carbon Dioxide Information Analysis center

As per WHO estimates, each year 2 million people die due to air pollution, which is harmful for both human and economy. Death caused due to pollution is more than smoking, the fine particular matter[3] are most damaging to human health. As per WHO, "worldwide air pollution causes 120 extra deaths in every 100,000 people per year, where in Europe a higher rate of 200 in 100,000 is recorded (Thomson Reuters Foundation from World Economic Forum, 2019). Table 3 provides the details of Average life expectancy lost Per Person, the toper in the list is caused largely by burning Fossil fuels the average life expectancy is around 1.8 years per person followed by smoking which reduces the life expectancy by 1.6 years.

Table 3: Average life expectancy lost Per Person

\begin{tabular}{|c|c|}
\hline Indicator & $\begin{array}{c}\text { Years/mon } \\
\text { ths }\end{array}$ \\
\hline Particulate pollution & 1.8 years \\
\hline Smoking & 1.6 years \\
\hline $\begin{array}{c}\text { Alcohol and drugs use } \\
\text { handwashing }\end{array}$ & 11 months \\
\hline Road injuries & 7 months \\
\hline HIV/AIDS & 4.5 months \\
\hline Malaria & 4 months \\
\hline Tuberculosis & 4 months \\
\hline Conflict and terrorism & 3.5 months \\
\hline Source Air quaty & 22 days \\
\hline
\end{tabular}

Source: Air quality life index

The below pie chart 6 the data on death due to Air Pollution (Age - Standardized deaths per 100,000 people attribute to air pollution (2016)), death percent in
Afghanistan due to air pollution is about 31 , the main reason is due to fuel and pollution due to household works and that of India is 15 percent.

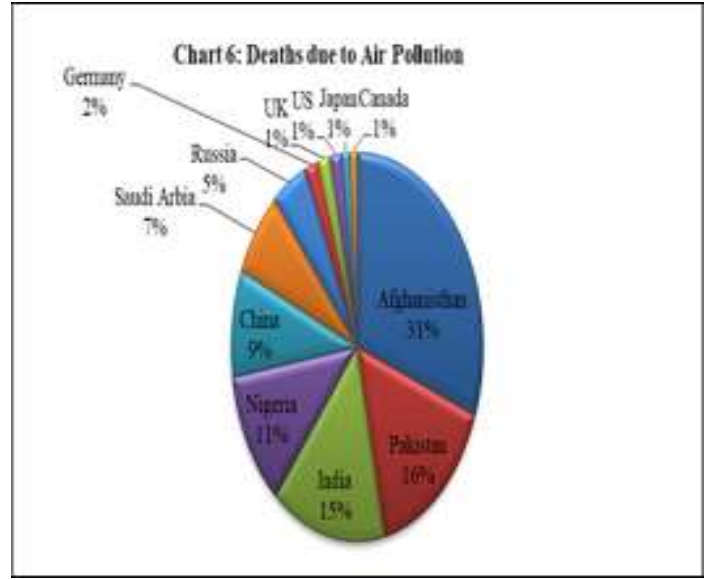

Source: computed from Health Effects institute: State of Global Air 2018

Every organisms on Earth depends on water for its daily survival, Increasing pollution degrades freshwater and coastal aquatic ecosystems. According to World Resources Institute (WRI) "the world's water systems face formidable threats. More than a billion people currently live in waterscarce regions, and as many as 3.5 billion could experience water scarcity by 2025 ".

Chart 7: waterless Countries

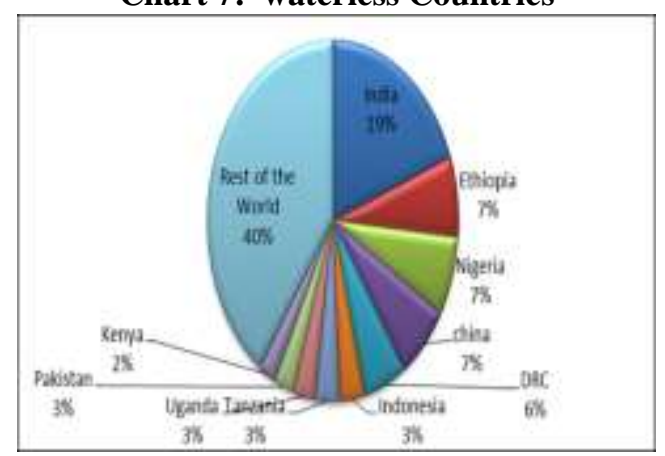

Source: computed from Source:The Water Gap-The State of the World's Water 2018.

With regards to Waterless Countries, just 10 countries accounts for 60 percent of the global population without access to clean water. The above pie chart reveals the top ten waterless countries, from the chart it is clear that India accounts for 19.33 percent, which is the foremost waterless economy according to The State of the World's Water 2018.

As per the United Nations list of countries by Urbanization levels, "India ranks 160th with around 34 percent of its population live currently in Urban area" (World Economic Forum, Jan 2019). The living standard has risen in urban India, where middle class consumers extend their purchasing power beyond their basic needs which tends to create new opportunities for international businesses thereby connecting digital technology.

Chart 8 compares the per capita emission rate of India with world. It is clear from the chart that pollution rate per capita is increasing drastically over the years. India stands 
first in waterless economy, third in death due to air pollution, third in carbon di oxide emission, all these are the consequences of urbanization.

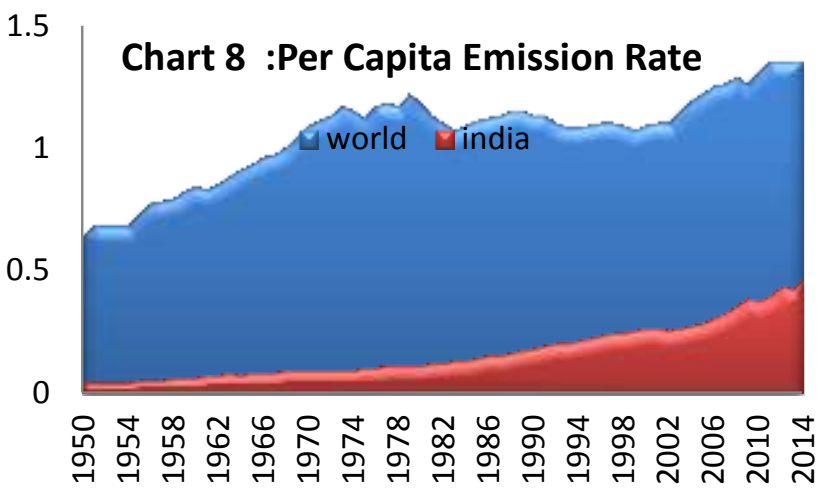

Source: computed from Carbon Dioxide Information Analysis

All emerging cities and nations are concentrating on creating a smart cities in order to reveal its strength and power. Few developing and developed economies are prepared for these challenges, and are capable of managing water scarcity, pollution, electricity consumption, population etc; the best example is Singapore. Infrastructural development does not mean destroying the nature. India has launched this smart city project, developing city implies Urbanization, To control the urbanization growth, villages must be targeted, if possible to strengthen the villages with quality education and hospital facilities instead of cities that will be a great start. It is worth to develop 100 smart villages than 100 thousand smart cities.

Table 4: Shades of green: Investment potential in cities by region and sector to 2030

\begin{tabular}{|c|c|c|c|c|c|c|c|}
\hline Regina & $\begin{array}{l}\text { Exs } \\
\text { Asi } \\
\text { Prifix }\end{array}$ & $\begin{array}{l}\text { Sounth } \\
\text { Axia }\end{array}$ & $\begin{array}{l}\text { Emripe } \\
\text { wal } \\
\text { Centril } \\
\text { dyia } \\
\end{array}$ & \begin{tabular}{|l|} 
Nididle \\
Eiss and \\
North \\
Sfirica \\
\end{tabular} & $\begin{array}{l}\text { Subt- } \\
\text { Sahher } \\
\text { Il } \\
\text { Africa }\end{array}$ & $\begin{array}{l}\text { Lain } \\
\text { Imprica } \\
\text { al } \\
\text { Caribtetall } \\
\end{array}$ & Iotdel \\
\hline Waste & $\begin{array}{l}\text { S82 } \\
\text { billon }\end{array}$ & $\begin{array}{l}522 \\
\text { billion }\end{array}$ & $\begin{array}{l}\text { S17 } \\
\text { billika }\end{array}$ & $\begin{array}{l}588 \\
\text { billina }\end{array}$ & $\begin{array}{l}\text { S13 } \\
\text { billion }\end{array}$ & sontion & $\begin{array}{l}5200 \\
\text { billika }\end{array}$ \\
\hline $\begin{array}{l}\text { Iencrible } \\
\text { enregy }\end{array}$ & $\begin{array}{l}5866 \\
\text { bilion }\end{array}$ & $\begin{array}{l}\text { S141 } \\
\text { bullion }\end{array}$ & \begin{tabular}{|l} 
SQ8 \\
billixa \\
\end{tabular} & \begin{tabular}{|l}
31 \\
bithon \\
\end{tabular} & $\begin{array}{l}589 \\
\text { billion }\end{array}$ & $\begin{array}{l}5266 \\
\text { billixa }\end{array}$ & $\begin{array}{l}\text { SE4? } \\
\text { billina }\end{array}$ \\
\hline $\begin{array}{l}\text { Pullic } \\
\text { traspontition }\end{array}$ & $\begin{array}{l}\text { S135 } \\
\text { blition }\end{array}$ & $\begin{array}{l}8217 \\
\text { billion }\end{array}$ & $\begin{array}{l}\text { S1l6 } \\
\text { billika }\end{array}$ & $\begin{array}{l}581 \\
\text { billixa }\end{array}$ & $\begin{array}{l}5159 \\
\text { billion }\end{array}$ & $\begin{array}{l}5109 \\
\text { billikn }\end{array}$ & $\begin{array}{l}\text { S1 } \\
\text { tithing }\end{array}$ \\
\hline $\begin{array}{l}\text { Climater } \\
\text { imat water }\end{array}$ & $\begin{array}{l}\text { S461 } \\
\text { bilion }\end{array}$ & $\begin{array}{l}\text { S110 } \\
\text { bullion }\end{array}$ & $\begin{array}{l}s 44 \\
\text { billikn }\end{array}$ & $\begin{array}{l}599 \\
\text { bithan } \\
\end{array}$ & $\begin{array}{l}101 \\
\text { billica }\end{array}$ & $\begin{array}{l}5288 \\
\text { billina }\end{array}$ & $\begin{array}{l}1 \\
\text { tniling } \\
\end{array}$ \\
\hline $\begin{array}{l}\text { Elettic } \\
\text { velidists }\end{array}$ & $\begin{array}{l}5669 \\
\text { billon } \\
\end{array}$ & $\begin{array}{l}\text { S214 } \\
\text { billion }\end{array}$ & $\begin{array}{l}346 \\
\text { billixa } \\
\end{array}$ & $\begin{array}{l}\text { S133 } \\
\text { bilhan } \\
\end{array}$ & $\begin{array}{l}\text { S34t } \\
\text { billion }\end{array}$ & $\begin{array}{l}5885 \\
\text { billixal } \\
\end{array}$ & $\begin{array}{l}81.6 \\
\text { tinlibn } \\
\end{array}$ \\
\hline $\begin{array}{l}\text { Gretn } \\
\text { buildings }\end{array}$ & $\begin{array}{l}\text { S16 } \\
\text { tilliou }\end{array}$ & $\begin{array}{l}518 \\
\text { tillima } \\
\end{array}$ & $\begin{array}{l}\text { S81 } \\
\text { billima } \\
\end{array}$ & $\begin{array}{l}1.1 \\
\text { tillion } \\
\end{array}$ & $\begin{array}{l}5768 \\
\text { billiou }\end{array}$ & St.1 allion & $\begin{array}{l}\text { S2.7.7 } \\
\text { trithon }\end{array}$ \\
\hline Total & $\begin{array}{l}\$ 175 \\
\text { tillion }\end{array}$ & $\begin{array}{l}82.5 \\
\text { trilika }\end{array}$ & $\begin{array}{l}81.2 \\
\text { trition } \\
\end{array}$ & $\begin{array}{l}1.7 \\
\text { tillion } \\
\end{array}$ & $\begin{array}{l}815 \\
\text { trilixn }\end{array}$ & Sitrtion & $\begin{array}{r}89.4 \\
\text { tonlibon } \\
\end{array}$ \\
\hline
\end{tabular}

Source: Climate Investment Opportunities in Cities An International Finance Corporation (IFC)Analysis
Table 4 presents the Investment potential in cities by region. It is clear from the table that green investment is and sector to 2030 and table 5 provides the total investment opportunities by 2030 in cities by region, based on urban population projections and emission reduction targets. A cumulative climate investment opportunity of \$29.4 trillion by 2030 (based on urban population) is estimated across six urban sectors in emerging market cities. The East Asia Pacific cities requires half of this investment. All these climate policies, targets, and goals may not be possible to achieve with 2030, but working for achievement is itself .

Table 5: Total investment opportunities by 2030 in cities by region, based on urban population projections and emission reduction targets

\begin{tabular}{|c|c|c|c|c|c|c|c|}
\hline RECWOS: & $\begin{array}{l}\text { Toilitu } \\
\text { mping } \\
\text { uIfC } \\
\text { resil }\end{array}$ & 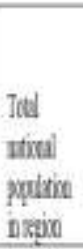 & $\begin{array}{l}\text { Titea } \\
\text { Mplibin } \\
\text { ilat }\end{array}$ & 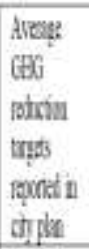 & 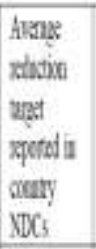 & 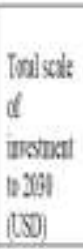 & $\begin{array}{l}\text { Propol } \\
\text { monim }\end{array}$ \\
\hline $\begin{array}{l}\text { Easilis } \\
\text { Paif: }\end{array}$ & 1,403 & $212 \mathrm{~N}$ & 695 & Sh & 35 & $17,8 \times B$ & an. \\
\hline Sachisis & $89 \mathrm{~N}$ & $2045 \mathrm{~N}$ & W & 55 & 23 & 2HEB & $\theta$ \\
\hline $\begin{array}{l}\text { Enge ad } \\
\text { Cand Asi }\end{array}$ & IMN & $380 \mathrm{X}$ & 63 & 38 & 30 & 1.21:B & 4 \\
\hline 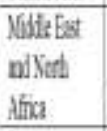 & $35 \mathrm{~N}$ & $52 x$ & $6 \%$ & 28 & 13 & $1.99 \mathrm{~B}$ & $\theta$ \\
\hline $\begin{array}{l}\text { Sthistexn } \\
\text { Afina }\end{array}$ & $B S N$ & $L 163 \mathrm{~N}$ & $8 \mathrm{~s}$ & 315 & $n_{3}$ & 1.A73B & 5. \\
\hline 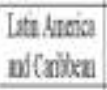 & $53 \mathrm{~N}$ & $713)$ & 4 & 25 & $18 \%$ & $5,6 \% 8$ & 178 \\
\hline Iod & in:M & $12 M \mathrm{~N}$ & 洪 & & & $9, \$ B B$ & 100 \\
\hline
\end{tabular}

Source: Climate Investment Opportunities in Cities An International Finance Corporation (IFC) Analysis

\section{CONCLUSION AND POLICY SUGGESTIONS}

Environmental degradation leads to less resistant humans and the communities they live in to become less equitable. Indian government encourages agricultural development, hydro power plant project and renewable capacity expansion more important to rural and urban developments. Fortunately, technological interventions are at hand to reduce and control pollution and climate changes. India has launched the smart city project. Infrastructural development does not mean destroying the nature. Developing city indicates Urbanization, but when ponds and lakes are transformed into flats, this increases water scarcity, pollution and less absorption capacities of soil .To control the urbanization growth, villages must be targeted, it possible to strengthen the villages instead of cities . Smart class rooms, good and healthy environment and hospitals must be focused and developed in villages (smart village) it will act as a tool to achieve 2030 sustainable development Goal. 
Hence the following policy measures are provided to tackle pollution (i) 3/4th of the India's poor live in rural areas. food production must definitely be increased by 50 or 100 percent by 2050 , by improving the agricultural methods so farmers and cultivating land (food production) must be take care of (ii) Urban structure to be followed in rural areas, Inclusive developments like Smart class rooms, clean and healthy environment and hospitals must be focused.(iii) by adopting ecofriendly policies and investment the pollution can be reduced.(iv) energy efficient technologies must be implemented in Industries and businesses (v) introduce stringent emission standards by promoting zeroemissions vehicles and establishing zero emission areas.

\section{End note:}

[1] Also, in 2017 the main contributers of CO2 emission China (27 per cent), US (15 per cent), the European Union (10 per cent) and India ( 7 per cent) covered 58 per cent of global emissions and the rest of the world contributed 41 per cent (The Hindu Business Line).

[2] https://www.theguardian.com/environment/2013/dec/31/pla net-will-warm-4c-2100-climate

[3] microscopic particles 20 times smaller than the width of a human hair, like metals, organic compounds or the byproducts of combustion from coal fire stations, wood and charcoal burning stoves, vehicle engines and factories

Appendix I:

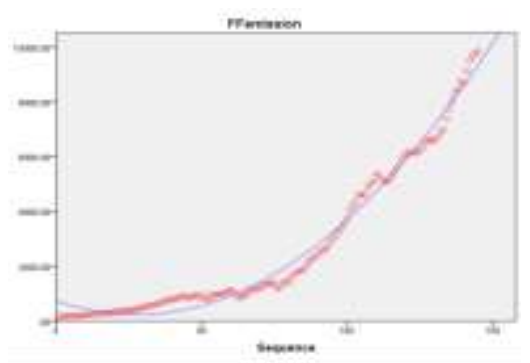

\section{REFERENCES}

1. Amit Garg , P.R.Shukla, Bhushan Kankal c and Diptiranjan Mahapatra ( 2017). CO2 emission in India: trends and management at sectoral, sub-regional and plant levels, Carbon Management, 8:2, 111-123, DOI: 10.1080/17583004.2017.1306406.

2. Boden, T.A., G. Marland, and R.J. Andres. 2017. Global, Regional, and National Fossil-Fuel CO2 Emissions. Carbon Dioxide Information Analysis Center, Oak Ridge National Laboratory, U.S. Department of Energy, Oak http://cdiac.ornl.gov/trends/emis/overview_2014.html.

3. Katharine Ricke, Laurent Drouet, Ken Caldeira and Massimo Tavoni (2018).Nature Climate Change, Vol 8.October 2018, 895-900, www.nature.com/natureclimatechange, https://doi.org/10.1038/s41558-018-0282-y

4. Ramachandra T.V., Bharath H.Aithal and K.Sreeejith ( 2015).GHG footprint of major cities in India, Renewable and sustainable Energy reviews 44 (2015) 473-495.

5. Rugayah Hashim and Nurul Dalina Mohamad Ristak, Normarliana Laili (2016).Attitudes toward Environmental Democracy among Urban Communities, thAcE-Bs2016Taipei, Taiwan, 09-10 Apr. 2016 / E-BPJ, 1 (3), August $2016 \quad$ (Pp.33-42). DOI: http://dx.doi.org/10.21834/e-bpj.v1i3.346 Ridge, Tenn., U.S.A. doi 10.3334/CDIAC/00001_V2017.

\section{REPORTS}

6. Climate Investment Opportunities in Cities An IFC Analysis 2018. International Finance Corporation and World Bank group, creating markets and creating opportunities, www.ifc.org

7. Dhingra, S. Mehta, R. (2017). AFOLU Emissions Version 2.0 dated September 28, 2017, from GHG platform India: 2005-2013 http://ghgplatform-

india.org/data-and-emissions/afolu.html

8. Food and Agriculture Organization of the United Nations (FAO). 2016. FAOSTAT Emissions Database. Rome, Italy: FAO. Available at: http://www.fao.org/faostat/en/\#data

9. Health Effects Institute. 2018. State of Global Air 2018 Special Report. Boston, MA:Health Effects Institute. www.stateofglobalair.org.

10. Health Effects Institute. 2019. State of Global Air 2019, www.stateofglobalair.org.

11. India's First Biennial Update Report (BUR) to the UNFCCC, 2015.

12. Introducing the Air Quality Life Index 2018, Human Health, and Global Policy by Michael Greenstone and Claire Qing Fan, Energy Policy Institute at the University of Chicago,https://aqli.epic.uchicago.edu/wpcontent/uploads/2018/11/AQLI-Report.111918-2.pdf.

13. International Energy Agency (IEA). 2016. CO2 Emissions from Fuel Combustion (2016 edition). Paris, France: OECD/IEA. Available online at:http://data.iea.org/ieastore/statslisting.asp. OECD/IEA, [2016].

14. The Special Report on Global Warming of $1.5{ }^{\circ} \mathrm{C}$ (SR15),published by the Intergovernmental Panel on Climate Change (IPCC) on 8 October 2018., www.ipcc.ch.

15. United Nations Conference on Environment and Development(1992), Agenda 21, \& 8.7.

16. Unlocking the Inclusive Growth Story of the 21st Century: Accelerating Climate Action in Urgent Times, New Climate Economy report 2018. New Climate Economy c/o World Resources Institute, www.newclimateeconomy.report,www.newclimateecono my.net

17. U.S. Energy Information Administration (EIA). 2016. International Energy Statistics Washington, DC: U.S Department of Energy. http://www.eia.gov/beta/international/data/browser

18. U.S. Environmental Protection Agency (EPA). 2012 "Global Non-CO2 GHG Emissions: 1990-2030." Washington, DC: EPA. Available at: https://www.epa.gov/global-mitigation-non-co2greenhouse-gases/non-co2-greenhouse-gasesinternational-emissions.

19. World Bank. 2017. World Development Indicators Washington, DC. Available at: http://data.worldbank.org/. Accessed September 28th, 2017.

20. World Resources Institute(1996). World Resources 1996-1997(173)

\section{E-RESOURCES}

21. https://www.wired.com/story/jakarta-is-sinking/

22. https://en.wikipedia.org/wiki/Paris_Agreement

23. https://www.theguardian.com/environment/2013/dec/31/ planet-will-warm-4c-2100-climate

24. https://www.thehindubusinessline.com/news/global- 
emissions-india-4th-highest-emitter-of-co2study/article25677626.

25. https://www.thehindubusinessline.com/news/globalemissions-india-4th-highest-emitter-of-co2study/article25677626.ece $2 / 2$

26. Networks and Systems (Book style). Belmont, CA: Wadsworth, 1993, pp. 123-135.

27. H. Poor, An Introduction to Signal Detection and Estimation. New York: Springer-Verlag, 1985, ch. 4.

28. B. Smith, "An approach to graphs of linear forms (Unpublished work style)," unpublished.

29. E. H. Miller, "A note on reflector arrays (Periodical style-Accepted for publication)," IEEE Trans. Antennas Propagat., to be published.

30. J. Wang, "Fundamentals of erbium-doped fiber amplifiers arrays (Periodical style-Submitted for publication)," IEEE J. Quantum Electron., submitted for publication.

31. C. J. Kaufman, Rocky Mountain Research Lab., Boulder, CO, private communication, May 1995

32. Y. Yorozu, M. Hirano, K. Oka, and Y. Tagawa, "Electron spectroscopy studies on magneto-optical media and plastic substrate interfaces(Translation Journals style)," IEEE Transl. J. Magn.Jpn., vol. 2, Aug. 1987, pp. 740-741 [Dig. 9th Annu. Conf. Magnetics Japan, 1982, p. 301].

33. M. Young, The Techincal Writers Handbook. Mill Valley, CA: University Science, 1989.

34. (Basic Book/Monograph Online Sources) J. K. Author. (year, month, day). Title (edition) [Type of medium]. Volume(issue). Available: http://www.(URL)

35. J. Jones. (1991, May 10). Networks (2nd ed.) [Online]. Available: http://www.atm.com

36. (Journal Online Sources style) K. Author. (year, month). Title. Journal [Type of medium]. Volume(issue), paging if given. Available: http://www.(URL)

\section{AUTHORS PROFILE}

Dr. Kadalarasane an Engineering graduate, has completed his Ph.D in Management. His area of specializations are Green finance, Behavioral Finance, Banking Technology management, International trade and Finance and International banking, He is well
versed with softwares like SPSS, Basics of Python and and Finance and International banking, He is well
versed with softwares like SPSS, Basics of Python and database like CMIE PROWESS and BLOOMBERG. He is working as a faculty for past five years for M.Sc Quantitative Finance program in Pondicherry University. He has published around 14 papers in edited books, National and International journals. Currently he is working in the sustainable development goals where he has published papers on Carbon emission, gender equality, ICT, women entrepreneur etc.

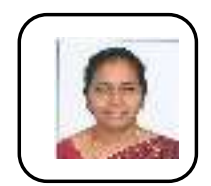

Dr. Tripura Sundari has completed her Ph.D. in Economics. She is working as a faculty for the past eight years for M.Sc Quantitative Finance program in Pondicherry University. Her area of specializations are Managerial/ Quantitative Economics, Econometrics, Time series Analysis \& Forecasting and Optimization techniques. She is well versed in software's like STATA, E-views, SPSS, Gretl, Minitab, R language, Basics of Python and database like CMIE PROWESS and BLOOMBERG. She has published 17 papers in National and International journals. Currently she is working on the sustainable development goals and published papers on Carbon emission, gender equality, ICT, women entrepreneurs etc. 